\title{
Effectiveness of reinforcing an earth structure with a system of counterfort drains over a long-term use
}

https://doi.org/10.2478/sgem-2018-0040

received May 25, 2018; accepted November 16, 2018.

Abstract: The paper evaluates the effectiveness of reinforcing a damaged earth structure with making counterfort drains in its slope. The system of counterfort drains changed the soil properties significantly over a long-term use. The evaluation was based on many years of field and laboratory tests and stability analysis. The field tests concerned the observation of $N_{\text {WST }}$ probing resistance change, and the laboratory tests concerned the change in soil consistency and water content. The paper presents the results of tests that were conducted over 13 years.

Keywords: counterfort drain, landslide, geotechnical monitoring, slope stability analysis, weight sounding test (WST), soil laboratory tests

\section{Introduction}

Counterfort drains are one of the oldest methods of improving slope stability by controlling the groundwater level on the one hand [1] and by applying an extra load on the side of retaining forces on the other hand [2]. Lowering the groundwater level by means of counterfort drains reduces the pore water pressure, thus increasing the effective soil shear strength along potential failure planes [3-5]. A system of counterfort drains in a slope significantly increases its stability at moderate construction costs $[3,5$, 6].

Counterfort drains are made below the groundwater level and the failure plane by cutting a system of trenches

\footnotetext{
*Corresponding author: Sebastian Olesiak, Faculty of Mining and Geoengineering, Department of Geomechanics, Civil Engineering and Geotechnics, AGH University of Science and Technology, 30-059 Kraków, al. Mickiewicza 30, pawilon A1, pok. 309, Poland, E-mail: olesiak@agh.edu.pl

Joanna Hydzik-Wiśniewska: Faculty of Mining and Geoengineering, Department of Geomechanics, Civil Engineering and Geotechnics, AGH University of Science and Technology, 30-059 Kraków, al. Mickiewicza 30, pawilon A1, pok. 309, Poland, tel. 126174796
}

1.0-2.0 $\mathrm{m}$ wide perpendicularly to the slope. The trench walls are reinforced with non-woven geotextile and side filled with all-in aggregate to protect the slope soil against suffusion. The trench is filled densely with coarse broken stone (stone wall) to the width $0.3-0.6 \mathrm{~m}$ less than the trench. Concrete troughs are laid on the counterfort bottom. A drainage line is made at the slope foot, and the collected groundwater is removed to a reservoir or an absorbing device [6-8]. Counterfort drains are often deep trenches perpendicular to the slope, protected with nonwoven geotextile and filled with aggregate. Drain pipes are laid on the bottom to remove the collected groundwater [3$6,9,10]$.

One of the basic design problems is a suitable location and depth of counterforts [11]. Deep drains (including counterfort drains) are usually designed using analytical methods [4]. These methods [12-14] are based on a number of assumptions concerning homogeneity and isotropy of the soil, permeability, porosity and boundary conditions. The occurrence of such conditions in the field is unlikely [11]. For this reason, Fitch [3], based on practical experience, presented guidelines for the placement and depth of counterforts and the predicted lowering of the groundwater level in the slope.

The stabilisation of slopes and embankments with counterfort drains has been used successfully worldwide $[9,10,15-17]$. Field studies conducted on structures indicate a large potential of counterforts to lower and stabilise the groundwater level over time [18, 3-6].

This paper evaluates the effectiveness of reinforcing a damaged retaining embankment of a landfill by making counterfort drains in its slope. The system of counterfort drains changed the soil properties significantly over a long-term use. The evaluation was based on many years of field and laboratory tests and stability analysis. The field tests concerned the observation of $N_{\text {WST }}$ probing resistance change, and the laboratory tests concerned the change in soil consistency and water content. The paper presents the results of that tests that were conducted over 13 years. 


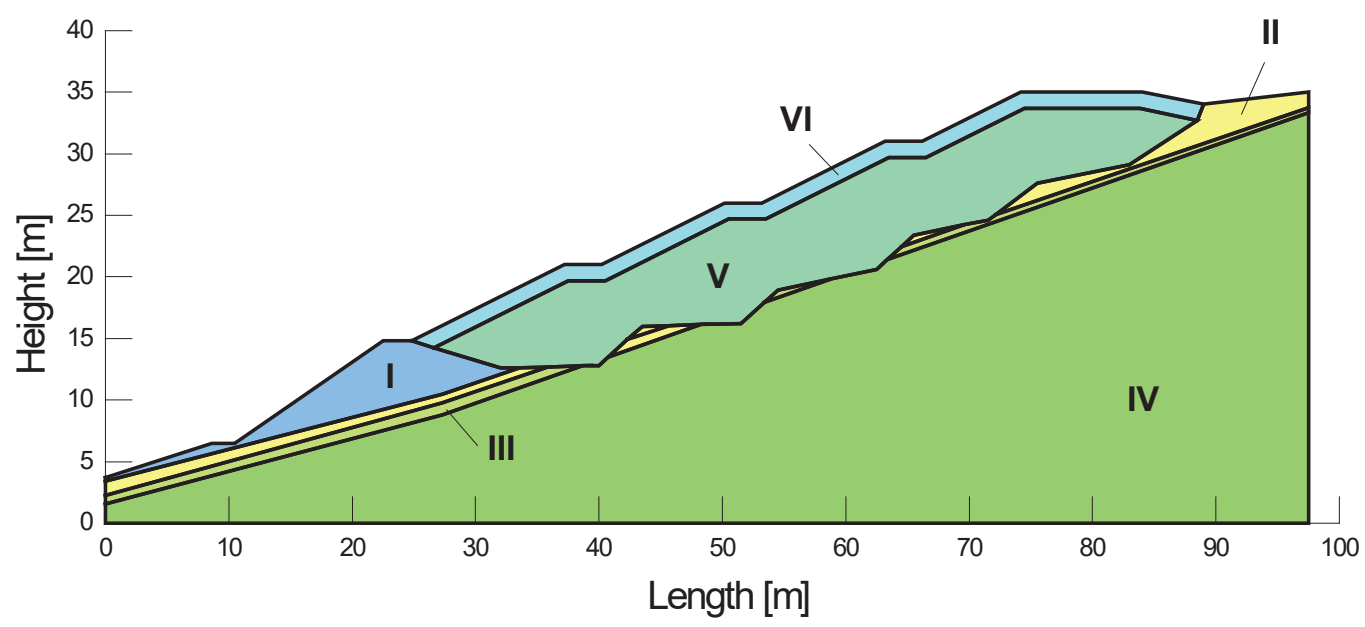

Figure 1: Landfill cross-section. I - retaining embankment, II - geotechnical layer II, III - geotechnical layer III, IV - geotechnical layer IV, V municipal waste and $\mathrm{VI}$ - organic layer

\section{Geotechnical problem}

The municipal landfill is situated within the administrative borders of Zakopane, Poland. It is located on a mountain slope, cut by an erosion valley connected with a local creek. The landfill is of a slope type, being a part of a steep hillside with inclination reaching $50 \%$ of exposure.

Figure 1 presents the landfill cross-section. In order to obtain a sufficient capacity of the landfill in a natural slope (II, III, IV), a hillside has been cut that comprised a few slopes and shelves. A retaining embankment (I) was built on the landfill front, forming the landfill trough. The outer retaining embankment side consists of two slopes and a shelf on which a technological road is located. The earth structure height varies from 8 to $12 \mathrm{~m}$, with a general inclination of about $30-32^{\circ}$ (1:1.5). The upper slope inclination reaches $38^{\circ}$. In such a designed landfill, the retaining embankment performs the retaining function to protect the final hillside shape, which is filled with municipal waste (V) and closed with the organic layer (VI).

Six months after the landfill opening (July 2004), after an intensive rainfall, a landslide in the retaining embankment occurred. The landslide included the top, outer embankment slope at the length of $>40 \mathrm{~m}$ and was asequent (Fig. 2a). The total loss of retaining embankment stability could lead to a construction and environmental disaster as a result of which the landfill would have had to be closed.

\section{Geotechnical tests of the retaining embankment slope}

All field works were performed manually due to the land configuration. The probing was performed using the weight sounding test (WST). A dozen probes were made in the area of the largest damage. The drilling was performed in the vicinity of the WST probing. A macroscopic soil evaluation was performed during the drilling, and samples were taken for laboratory tests. Manual drilling allowed testing of the layer up to $2.5 \mathrm{~m}$ deep.

The testing proved that the retaining embankment is made of indigenous soil obtained from the hillside terracing for the landfill. The soil is an uncontrolled mixture of sandy silty clay (sasiCl) and clay $(\mathrm{Cl})$ mixed with rocky material (mudstone and sandstone). The surface layers were in the very soft and soft consistency, deeper turning into the firm consistency. This statement is true for the whole retaining embankment, e.g. the top, slopes and the shelf on which the road is located. The firm consistency was achieved only at depths corresponding to natural subsoil and then gradually turned into a stiff consistency.

The reasons for the retaining embankment damage are extensively described in the paper [19]. The basic reasons include:

- the firm consistency of soils of which the retaining embankment was formed;

- forming of the retaining embankment directly on the natural slope;

- the absence of compaction control during the earthworks; 
a)

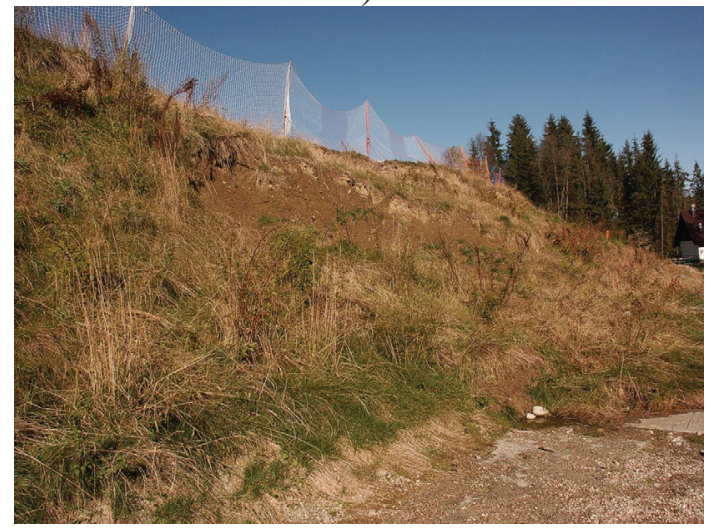

b)

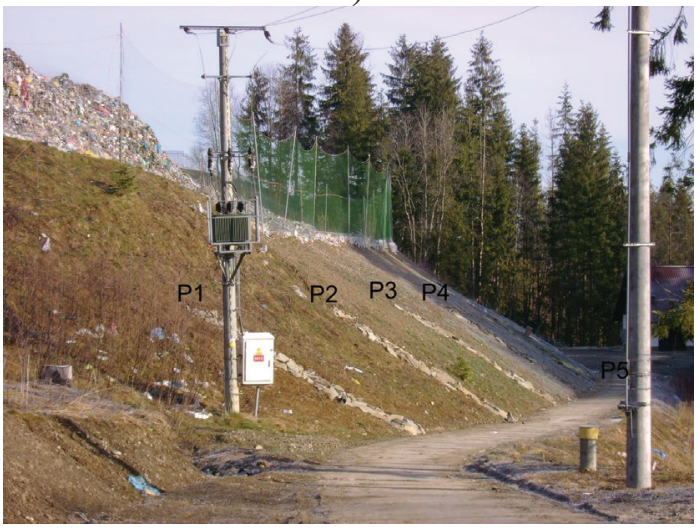

Figure 2: Landfill retaining embankment: a) damaged, 2004, and b) after repairs with counterforts P1-P5, 2005.

- the absence of drainage on the entire landfill area and

- the absence of any drainage treatment for correct water removal and soil consolidation in the retaining embankment.

\section{Geotechnical monitoring of the retaining embankment over a long-term use}

The final protection was not made for reasons of economy $[8,19]$; only a temporary protection was made that comprised a system of counterfort drains at the entire retaining embankment length (Fig. 2b). The counterfort drains were made by cutting eight trenches (P1-P8) 1.0 $\mathrm{m}$ wide and 5.0-7.0 $\mathrm{m}$ deep perpendicular to the slope. The distance between the counterforts was $15.0 \mathrm{~m}$. A drainage line was made below the counterforts to remove the groundwater to a nearby water course. The retaining embankment repair was completed in 2005.

Despite the recommendations, cyclical monitoring of the retaining embankment and all displacement was not introduced and piezometers were not installed. The absence of monitoring made it difficult to evaluate the protection effectiveness and control the structure behaviour. Therefore, the soil consistency and water content in the retaining embankment monitoring were provided by ourselves. The retaining embankment conditions were monitored between 2007 and 2017 by means of periodic WST probing. In addition, the samples were taken for laboratory tests from the surface layer (down to about $2.0 \mathrm{~m}$ below the ground). The field tests were performed in autumn during good weather.
The soil samples were not taken for strength and strain tests during the whole period of study for economic and technical reasons. Such tests require soil samples with intact structure and water content (NNS [20], quality class 1 [21]). No suitable equipment and financial resources were available for such sampling.

The WST probing was performed at six points in the area of the largest embankment damage in 2004, at a halfway distance between the counterforts P1/P2, P2/P3 and $\mathrm{P} 3 / \mathrm{P} 4$. Three probes were made into the soil from the top of embankment WST-1, WST-3 and WST-5, and the other three were made at a half-height of the top embankment slope WST-2, WST-4 and WST-6. Additional WST probing was made between counterforts P4/P5, WST-7 and WST-8 since 2007 (Fig. 3).

The WST probing results are shown in Figs. 4-7, by comparing the probing from the top of the retaining embankment with the probing at the half-height of the slope.

The following numerical weights were applied for the WST probing in cases where the probe penetrates statically only as a result of applied load $N_{W S T}: 0$ for $1.0 \mathrm{kN}$, -1 for $0.75 \mathrm{kN},-2$ for $0.5 \mathrm{kN},-3$ for $0.25 \mathrm{kN}$ and -4 for $0.05 \mathrm{kN}$.

At the field test stage, the peak $N_{\text {WST }}$ values that indicated the presence of obstacles (rocks) were recorded in the probing sheets. When the probing results were processed, these values were replaced with a mean from two neighbouring $N_{\text {WST }}$ probings (below and above the peak value).

Analysis of the probing results indicates an increased number of $N_{\text {WST }}$ half-turns in the total WST probing profile in successive years. Since 2013, the results of WST probing have stabilised. A very quick improvement of soil conditions in the area near surface should be noted 


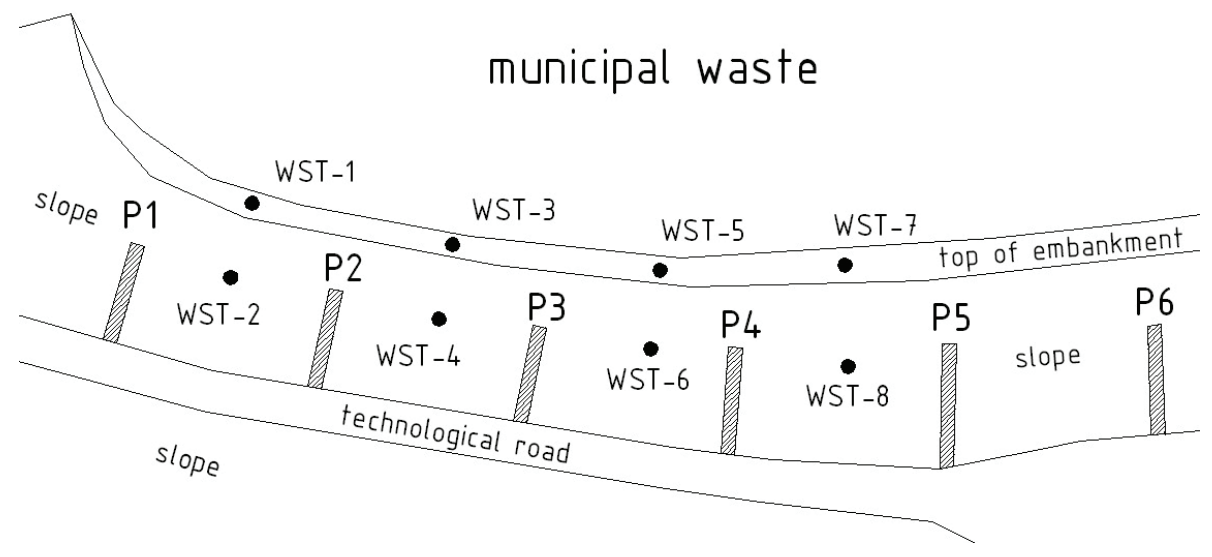

Figure 3: Location of the WST probing.

a)

Number of half-turns $N_{\text {WST }}$ for every $10 \mathrm{~cm}$ of WST probe penetration

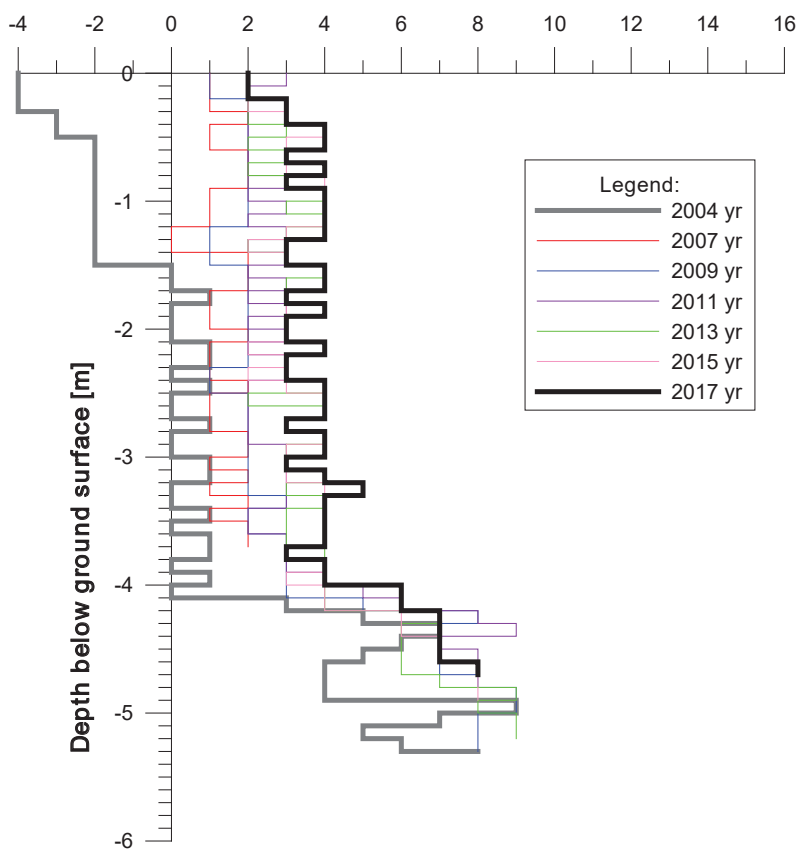

b)

Number of half-turns $N_{\text {wST }}$ for every $10 \mathrm{~cm}$ of WST probe penetration

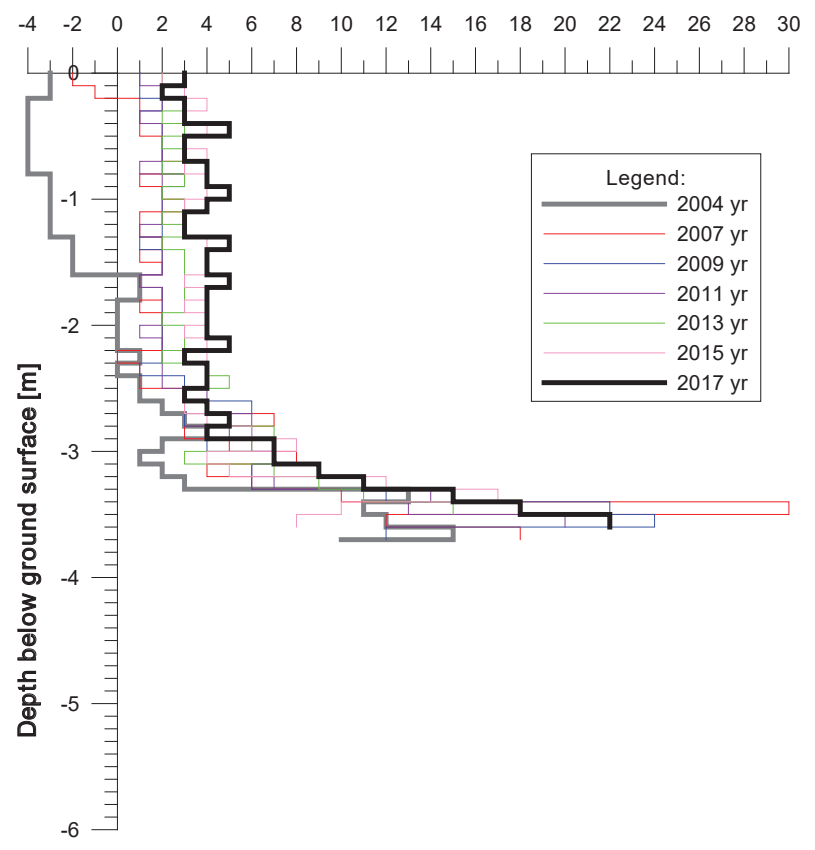

Figure 4: WST probing results between counterforts P1 and P2: a) WST-1 and b) WST-2.

(Figs. 4, 5 and 6b). Based on nomographs [22], it is easy to determine the soil consistency changes in the retaining embankment and its subsoil. This estimate indicates that from 2004, the soil changed from the soft consistency $N_{\text {WST }}$ $\approx-3(0.25 \mathrm{kN})$ to the stiff consistency $N_{\text {WST }} \approx 3$ in 2013. The sharp increase in the $N_{\text {WST }}$ seen in the graphs corresponds to the level of natural layers.

The drilling with soil sampling was conducted in three points from the top of the embankment near the WST-1, WST-2 and WST-3 probing locations. During the laboratory tests in successive years, the following retaining embankment soil properties were determined: water content $w$, plastic limit $w_{P}$ and liquid limit $w_{L}$ using the Casagrande method (Table 1). These values were the basis for determining the changes in soil liquidity index $I_{L}$ (Fig. 8) and consistency. 
a)

Number of half-turns $N_{\text {wST }}$ for every $10 \mathrm{~cm}$ of WST probe penetration

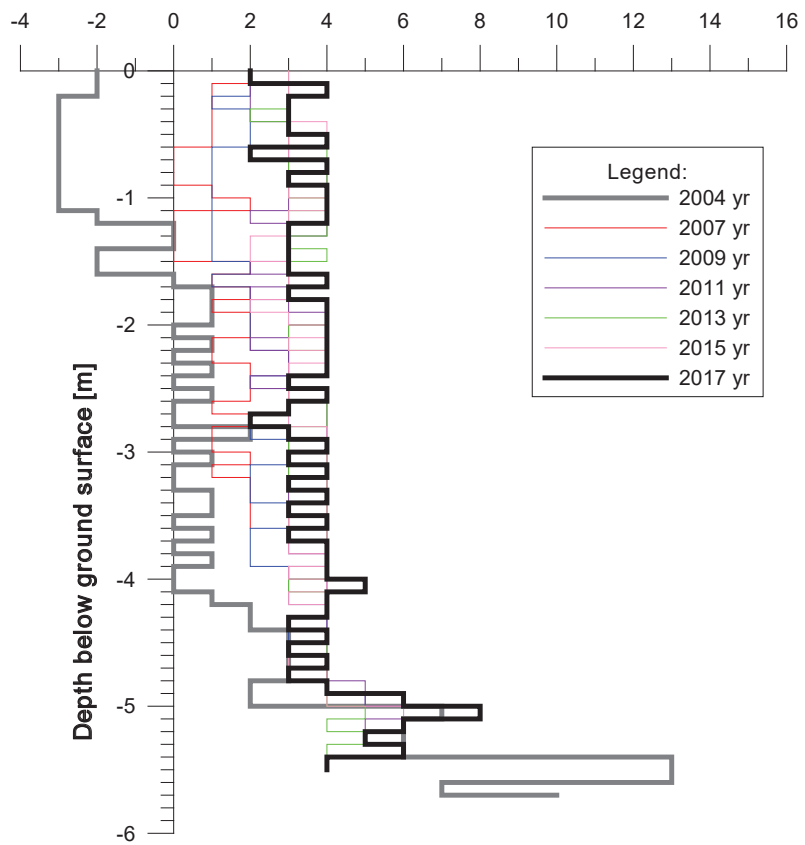

b)

Number of half-turns $N_{\text {wST }}$ for every $10 \mathrm{~cm}$ of WST probe penetration

Figure 5: WST probing results between counterforts P2 and P3: a) WST-3 and b) WST-4.

a)

Number of half-turns $N_{\text {wST }}$ for every $10 \mathrm{~cm}$ of WST probe penetration

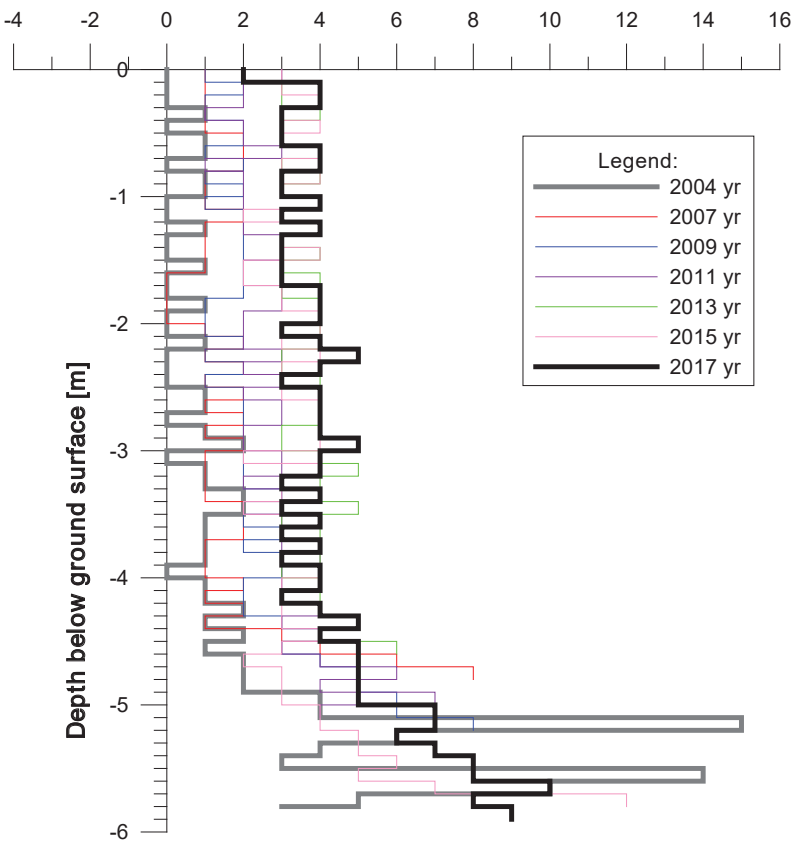

b)

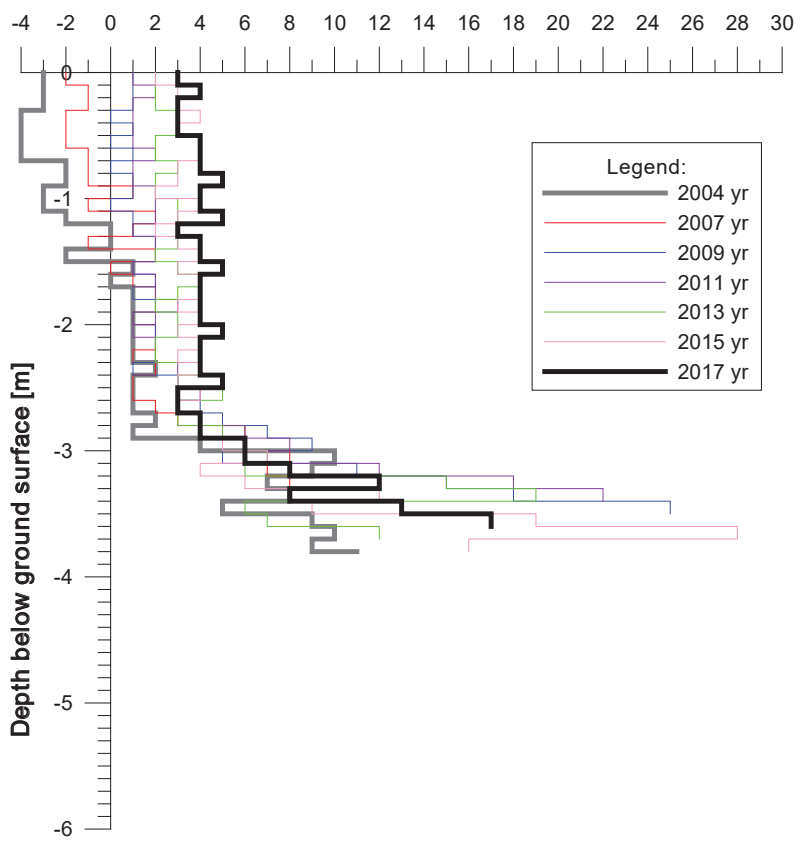


a) Number of half-turns $N_{\text {wST }}$ for every $10 \mathrm{~cm}$ of WST probe penetration b)

Number of half-turns $N_{\text {wST }}$ for every $10 \mathrm{~cm}$ of WST probe penetration

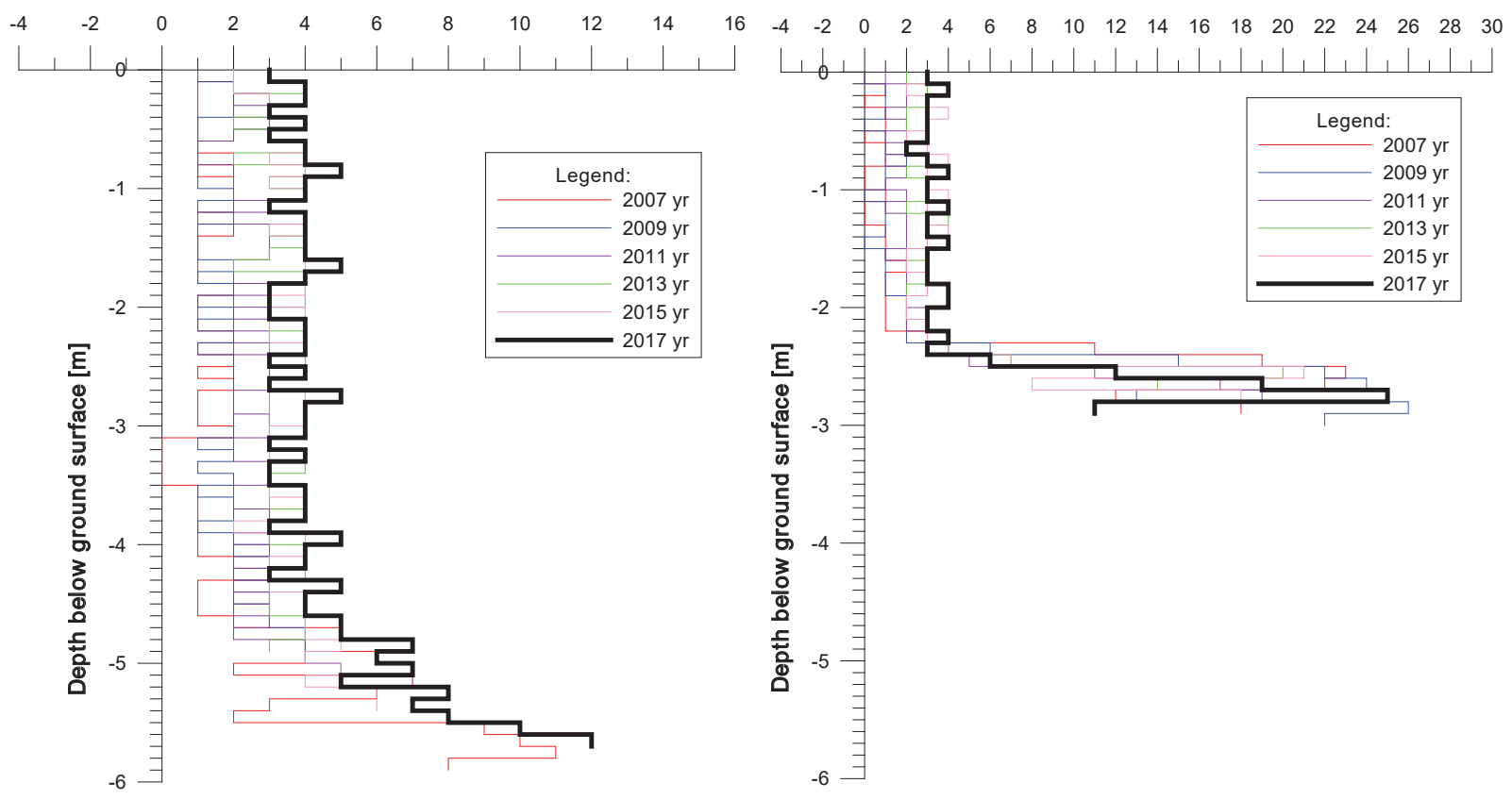

Figure 7: WST probing results between counterforts P4 and P5: a) WST-7 and b) WST-8.

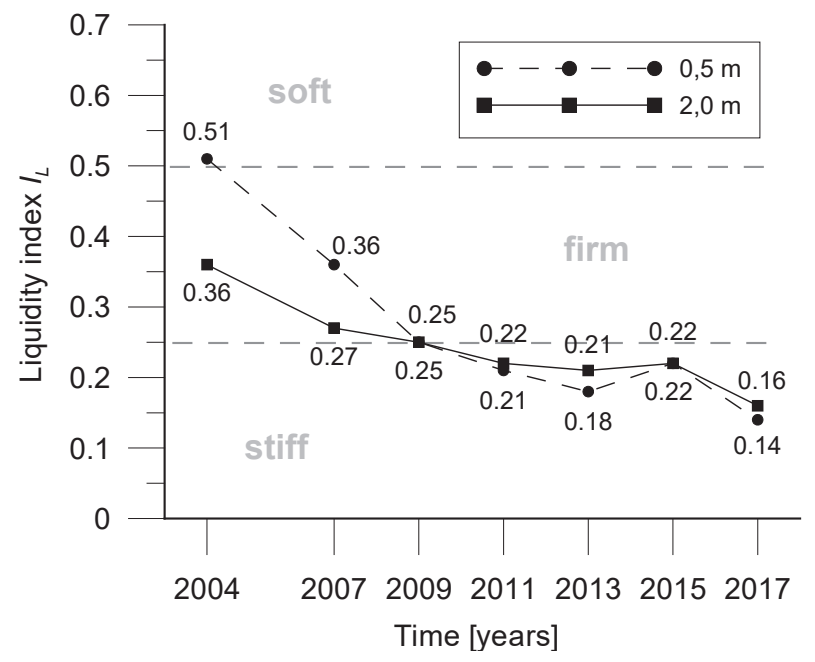

Figure 8: Changes in the retaining embankment soil liquidity index (mean values from three boreholes).

The results of the laboratory tests confirm the improvement of retaining embankment soil consistency. Stabilisation of the water content and liquidity index is visible as early as in 2011.

\section{Landfill stability analysis}

The effectiveness of the temporary retaining embankment protection was also proved using the landfill stability analysis, taking into account the change in soil properties over time.

The SLOPE/W software was used to perform the calculations. The software allows for a stability analysis with the limit equilibrium method. The grid and radius method [23] was applied to determine the minimum factor of safety. The adequate safety over a long-term use requires that the factors of safety are $\geq 1.5[24]$.

The retaining embankment soil parameters, depending on the varying liquidity index $I_{L}$, are presented in Table 2. Based on the WST probing results, it was assumed that up to 2011, the soils in the retaining embankment were non-consolidated (curve C, [25]). Stabilisation of the WST probing results has been visible since 2013. As no consolidometer measurements were performed, it is not possible to determine unambiguously whether the consolidation process is complete. Therefore, mean values determined from curves $\mathrm{C}$ and $\mathrm{B}$ for a given liquidity index were used in the calculations [25]. 
Table 1: Laboratory test results in successive years (mean values from three boreholes).

\begin{tabular}{lllllllll}
\hline Properties & Depth [m] & Years & & & & & & \\
& & $\mathbf{2 0 0 4}$ & $\mathbf{2 0 0 7}$ & $\mathbf{2 0 0 9}$ & $\mathbf{2 0 1 1}$ & $\mathbf{2 0 1 3}$ & $\mathbf{2 0 1 5}$ & $\mathbf{2 0 1 7}$ \\
\hline Water content, $w[\%]$ & 0.5 & 38.13 & 33.81 & 30.74 & 29.64 & 29.01 & 30.17 & 28.13 \\
& 2.0 & 34.14 & 31.41 & 30.78 & 30.06 & 29.42 & 30.20 & 28.46 \\
Plastic limit, $w_{P}[\%]$ & 0.5 & 24.74 & 24.05 & 24.17 & 24.06 & 24.63 & 24.24 & 24.24 \\
& 2.0 & 24.87 & 24.15 & 24.12 & 23.98 & 23.98 & 25.04 & 24.26 \\
Liquid limit, $w_{L}[\%]$ & 0.5 & 51.15 & 51.02 & 50.44 & 50.57 & 49.65 & 51.07 & 51.11 \\
& 2.0 & 50.60 & 50.84 & 50.65 & 51.21 & 49.85 & 48.96 & 50.05 \\
\hline
\end{tabular}

Table 2: Retaining embankment soil parameters by liquidity index $I_{L}$ used in the stability calculations.

\begin{tabular}{llllllll}
\hline Properties & Years & & & & & \\
& $\mathbf{2 0 0 4}$ & $\mathbf{2 0 0 7}$ & $\mathbf{2 0 0 9}$ & $\mathbf{2 0 1 1}$ & $\mathbf{2 0 1 3}$ & $\mathbf{2 0 1 5}$ & $\mathbf{2 0 1 7}$ \\
\hline Liquidity index, $I_{L}$ & $0.36, \mathrm{C}$ & $0.27, \mathrm{C}$ & $0.25, \mathrm{C}$ & $0.22, \mathrm{C}$ & $0.21, \mathrm{C} / \mathrm{B}$ & $0.22, \mathrm{C} / \mathrm{B}$ & $0.16, \mathrm{C} / \mathrm{B}$ \\
Unit weight, $\gamma\left[\mathrm{kN} / \mathrm{m}^{3}\right]$ & 20.0 & 20.0 & 20.0 & 21.0 & 21.0 & 21.0 & 21.0 \\
Cohesion, $c_{u}[\mathrm{kPa}]$ & 12.0 & 14.0 & 15.0 & 17.0 & 24.0 & 23.0 & 26.0 \\
Angle of internal friction, $\phi_{u}\left[^{\circ}\right]$ & 12.0 & 13.5 & 14.0 & 14.5 & 16.5 & 16.3 & 17.5 \\
\hline
\end{tabular}

C - non-consolidated soils, B - consolidated soils, C/B - the arithmetic mean values from B and C curves

Table 3: Parameters of the geotechnical layers used in the stability calculations [26, 27].

\begin{tabular}{llll}
\hline Geotechnical layer & Volumetric weight, $\gamma\left[\mathrm{kN} / \mathrm{m}^{3}\right]$ & Cohesion, $c_{u}[\mathrm{kPa}]$ & Angle of internal friction, $\phi_{u}\left[^{\circ}\right]$ \\
\hline II (sasiCl $\left./ \mathrm{Cl}, I_{L}=0.15\right)$ & 20.8 & 45.0 & 9.9 \\
III (Co and sasiCl/Cl, $\left.I_{L}=0.05\right)$ & 20.6 & 46.8 & 10.8 \\
IV (Carpathian flysch) & 22.0 & 63.0 & 36.0 \\
V (municipal waste) & 11.0 & 10.8 & 19.8 \\
VI (organic soil) & 16.0 & 13.0 & 3.2 \\
\hline
\end{tabular}

sasiCl - silty clay, $\mathrm{Cl}$ - clay, Co - cobble

It is generally believed that soil properties presented in standard [25] are underestimated and the design based on them (method B) is safe.

Table 3 presents the parameters of the other soil layers used in the stability calculations. For municipal waste (V) and organic layer (VI), the properties were taken from the literature [26]. However, for natural layers (II, III and IV), the soil properties were taken from the geological documentation prepared for the landfill construction [27].

The total values of the angle of internal friction $\phi_{u}$ and cohesion $c_{u}$ were used in the calculations. Only the total values of $\phi_{u}$ and $c_{u}$ were available for the natural layer (II, III and IV) [27], the municipal waste layer (VI) and organic layer (VI) [26]. Thus, such values were consistently used for the retaining embankment (I). Using the total parameters

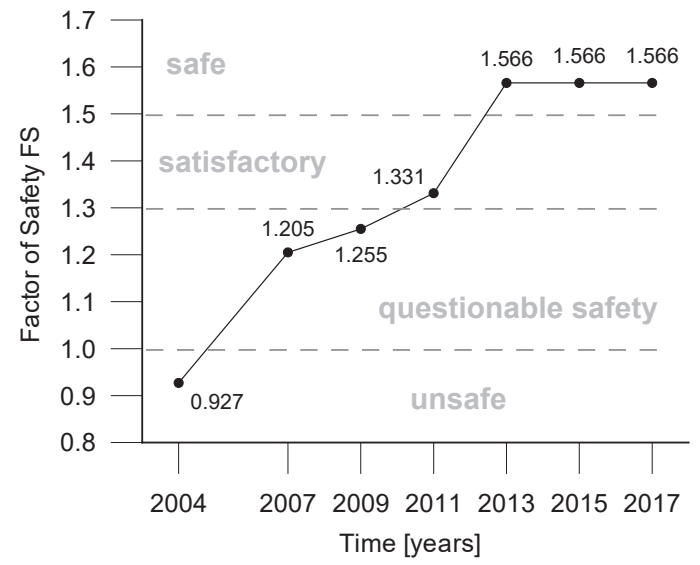

Figure 9: Stability analysis results (Bishop's method) 
a)

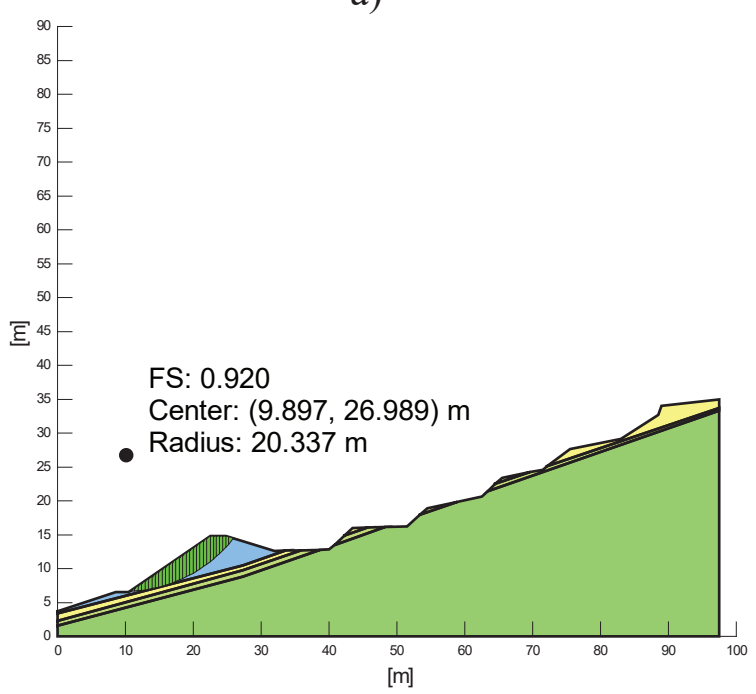

c)

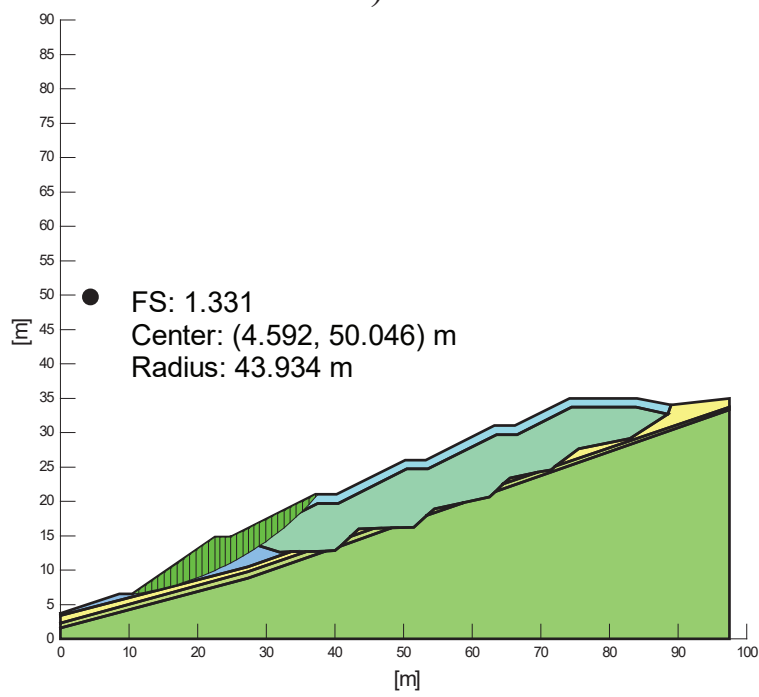

b)

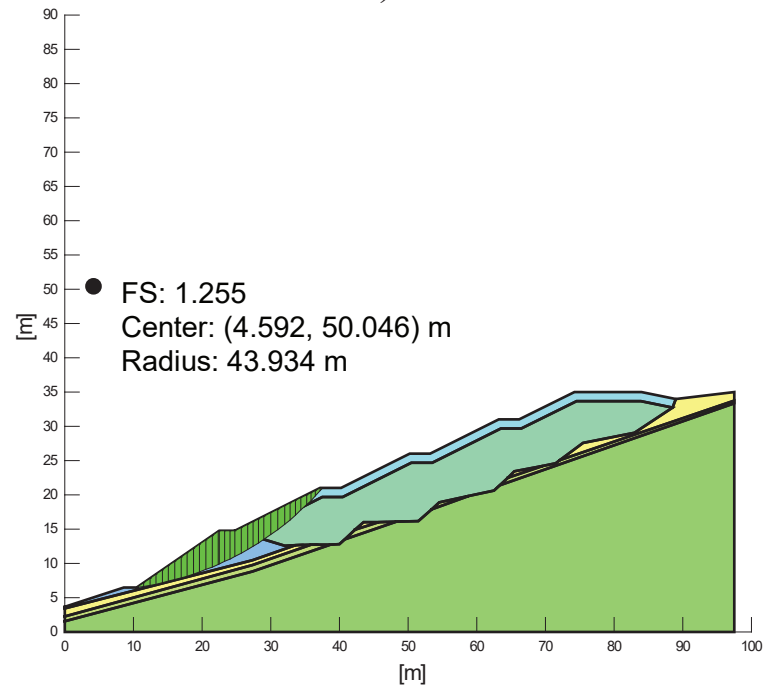

d)

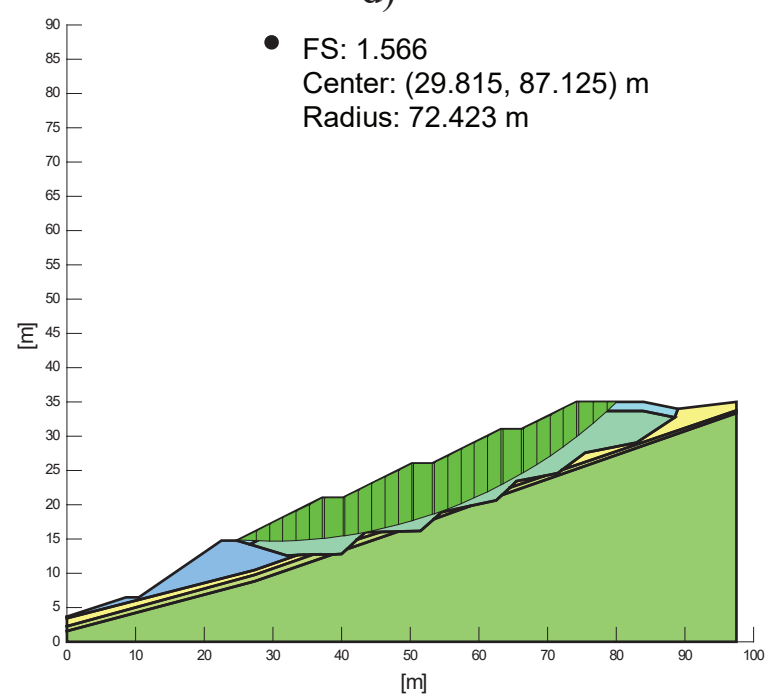

Figure 10: Selected stability analysis results (Bishop's method): a) only the retaining embankment 2004, b) 2009, c) 2011 and d) 2013,2015 and 2017 (identical results).

of $\phi_{u}$ and $c_{u}$ and omitting the pore pressure $u$ are accepted in the stability analysis [28].

The effective parameters have greater values of the angle of internal friction and lower cohesion values than the total values. It is noted in particular for highliquidity index soils, $I_{L}>0.25$ [28]. No piezometers were installed in the retaining embankment and its vicinity. An unambiguous determination of the ground water level was not possible. In such a case, if the effective parameters were used without accounting for pore pressure, the resulting factor of safeties would be much higher.
The calculations for each time variant were performed for the situation when the landfill was full of waste and covered with the organic layer. The stability analysis results are given in Fig. 9.

The empty landfill stability analysis was performed for the situation in July 2004 (Fig. 10a). The factor of safety $(\mathrm{FS}=0.920)$ confirms the stability loss of the retaining embankment.

Analysis of the values from the performed stability calculations indicates that in the case when the retaining embankment soil is firm consistency, the factors of safety 
(FS < 1.3) are unsatisfactory from the point of view of landfill stability. The corresponding failure planes run through the retaining embankment (Fig. 10b). From 2011 onwards, when the retaining embankment soil is of a stiff consistency (FS > 1.3), the results are satisfactory and the landslide processes are unlikely (Fig. 10c). The analysis of the last three cases (FS > 1.5) indicates that the results are very satisfactory, and the corresponding failure planes are located in the slope part with the municipal waste (Fig. 10d).

\section{Conclusions}

The construction of counterfort drains stabilised the water conditions in the retaining embankment and accelerated the soil consolidation process. From 2007 onwards, the field tests did not indicate any groundwater seepage or leakage and cracks or landslides. The construction of counterfort drains improved the consistency of the retaining embankment soil. In 2010, when the landfill was closed, a horizontal drain was made in the top landfill part that additionally improved the soil and water conditions in the retaining embankment.

From 2011 onwards, when the retaining embankment soil has been of a stiff consistency ( $F S=1.331$ ), the results are satisfactory and the landslide processes are unlikely. Further consolidation and soil consistency changes improved the factor of safety in successive years (FS = 1.566).

A massive and dense counterfort structure also contributed to the improved retaining embankment stability.

Acknowledgement: This study is supported through the statutory research grant registered in AGH University of Science and Technology (No. 11.11.100.197).

\section{References}

[1] Henkel, D.J. (1957). Investigations of two long-term failures in London clay slopes at Wood Green and Northolt. In: Proceedings of the 4th International Conference on Soil Mechanics and Foundation Engineering, London, 12-24 August 1957. Butterworths Scientific Publications, London, pp. 315320.

[2] Furtak, K., Gaszyński J., Pabian Z. (2012). Geotechniczne systemy zabezpieczeń i stabilizacji na terenach osuwiskowych, cz.2. Nowoczesne Budownictwo Inżynieryjne, 1, 44-48, (in Polish).
[3] Fitch, N.R. (1990). Ground stabilisation with counterfort drains - design, installation and monitoring of drawdown performance. Proceedings NZ Geomechanics Society, 16, 1(G), 97-101.

[4] McDonald, G.J., Vooght, A.R., Parkin S. (2012). The use of deep counterfort drains as an effective method of stabilizing cuttings constructed in overconsolidated clays. Geological Society, London, Engineering Geology Special Publications, Earthworks in Europe, 26, 115-124.

[5] Torvelainen, S.M. (2016). Counterfort drain performance in the Auckland Area. In: Proceedings of the 11th ANZ Young Geotechnical Professionals Conference - 11YGPC, Queenstown, New Zealand, 25-28 October 2016. NZGS, Wellington, New Zealand, pp. 257-262.

[6] Price, S.L., Fitch N.R. (2017). Counterfort drains - design, installation and long-term performance in soils of Greater Auckland. In: Proceedings of 20th NZGS Geotechnical Symposium, Napier, 23-26 November 2017. NZGS, Wellington, New Zealand, pp. 193-200.

[7] Bolt, A. (2010). Gospodarka wodna na skarpach i obiektach drogowych. Drogi: lądowe, powietrzne, wodne, 5, 42-61, (in Polish).

[8] Flisiak, J., Olesiak S. (2005). Analiza warunków stateczności wału oporowego składowiska odpadów komunalnych oraz propozycje jego stabilizacji. Górnictwo i Geoinżynieria, 3/1 (29), 207-215, (in Polish).

[9] Dennison, D.L., Edger N.J. (2003). Design and construction of a large cut slope in sensitive volcanic ash soils. In: Geotechnics on the volcanic edge, New Zealand Geotechnical Society symposium, Tauranga, March 2003. IPENZ, Wellington, New Zealand, pp. 359-367.

[10] Kors-Olthof, R., Hoeve E., Patrick B. (2014). Evaluation and stabilization of a slope failure at Liard Highway No. 7, km 5.9 (Case Study). In: 67th Canadian Geotechnical Conference, GeoRegina 2014, Regina, Saskatchewan, September 28October 1. Canadian Geotechnical Society.

[11] Cornforth, D.H. (2005). Landslides in Practice - Investigation, Analysis and Remedial/Preventative Options in Soils. John Wiley \& Sons Inc, Hoboken, NJ.

[12] Bromhead, E.N. (1984). An analytical solution to the problem of seepage into counterfort drains. Canadian Geotechnical Journal, 21, 657-662.

[13] Hutchison, J.N. (1977). Assessment of corrective measures in relation to geological conditions and types of slope movement. Bulletin of the International Association of Engineering Geology, 16, 131-155.

[14] Stanić, B. (1984). Influence of drainage trenches on slope stability. Journal of Geotechnical Engineering, 110, 1624-1636.

[15] Leong, E.C., Rahardjo H. (2012). Two and three-dimensional slope stability reanalyses of Bukit Batok slope. Computers and Geotechnics, 42, 81-88.

[16] McNicholl, D.P., Pump W.L., Cho G.W.F. (1986). Groundwater control in large scale slope excavation - Five case histories from Honk Kong. Geological Society Engineering Geology Special Publication, 3, 513-523.

[17] O’Kelly, B.C., Ward P.N., Raybould M.J. (2008). Stabilization of a progressive railway embankment slip. Geomechanics and Geoengineering: An International Journal, 3(4), 257-270.

[18] Allison, J.A., Mawditt J.M., Williams G.T. (1991). The use of pored piles and counterfort drains to stabilize and major 
landslip - a comparison of theoretical and field performance. In: Slope stability engineering developments and applications: Proceedings of the international conference on slope stability organized by the Institution of Civil Engineers and held on the Isle of Wight on 15-18 April 1991. Thomas Telford, London, pp. 369-376.

[19] Olesiak, S. (2007). Składowisko odpadów komunalnych w Zakopanem - od awarii do zamknięcia I kwatery. In Materiaty Krakowskiej Konferencji Młodych Uczonych 2007, Kraków, 20-22 września 2007. GN ProFuturo, Kraków, pp. 325-333, (in Polish).

[20] Polski Komitet Normalizacyjny (1988). Polska Norma: Grunty budowlane. Badania próbek gruntu. PN-B-04481:1988. Warszawa, (in Polish).

[21] Polski Komitet Normalizacyjny (2009). Eurokod 7: Projektowanie geotechniczne. Część 2: Rozpoznanie i badanie podłoża gruntowego PN-EN 1997-2:2009. Warszawa, (in Polish).

[22] Olesiak, S. (2014). Ocena stopnia plastyczności itów mioceńskich na podstawie badań sondą wkręcaną WST. Inżynieria Morska i Geotechnika, 2, 112-117, (in Polish).

[23] GeoStudio (2008). Stability Modeling With Slope/W 2007 Version. GEO-SLOPE International Ltd, Calgary, Canada.

[24] Batog, A., Stilger-Szydto E. (2010). Stateczność skarp nasypów drogowych w ujęciu Eurokodu 7. Drogownictwo, 1, 18-21, (in Polish).

[25] Polski Komitet Normalizacyjny (1981). Polska Norma: Grunty budowlane. Posadowienie bezpośrednie budowli. Obliczenia statyczne i projektowe. PN-B-03020:1981. Warszawa, (in Polish).

[26] Pisarczyk, S. (2004). Grunty nasypowe. Wtaściwości geotechniczne i metody ich badania. OWPW, Warszawa, (in Polish).

[27] Dempol. (1997). Dokumentacja warunków hydrologicznych i geologiczno - inżynierskich terenu przeznaczonego pod budowę wysypiska odpadów „Zoniówka II” dla Zakopanego. Gorlice: Dempol, (in Polish, not published).

[28] Witun, Z. (2013). Zarys geotechniki. WKt, Warszawa, (in Polish). 